\title{
Minimally-invasive approach to parapharyngeal space: Extraordinary use of nasal speculum
}

\section{Parafarengeal bölgeye minimal invaziv yaklaşım: Nazal spekulumun olă̆an dışı kullanımı}

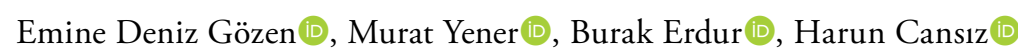

Department of Otolaryngology, Istanbul University Cerrahpaşa Faculty of Medicine, Istanbul, Turkey

\begin{abstract}
Objectives: This study aims to present our clinical experience and surgical outcomes of removal of parapharyngeal space (PPS) tumors by the use of Killian's nasal speculum for retraction of the surgical field and dissection of the mass.

Patients and Methods: This retrospective study included 13 patients (6 males, 7 females; median age 28 years; range, 3 to 63 years) diagnosed and surgically treated for PPS tumors between January 2014 and October 2017. All patients underwent nasal speculum-assisted transoral or transcervical excision.

Results: Nasal speculum-assisted transoral $(\mathrm{n}=4)$ or transcervical $(n=9)$ excision was performed to remove parapharyngeal mass. Four patients had malignant mass [rhabdomyosarcoma $(\mathrm{n}=1)$, low grade myofibroblastic sarcoma $(\mathrm{n}=1)$, malignant schwannoma $(n=1)$ and adenocarcinoma $(n=1)$ ] while nine patients had benign tumors: pleomorphic adenoma $(n=4)$, schwannoma $(n=3)$, paraganglioma $(n=1)$ and ganglioneuroma $(n=1)$. Postoperative complications were unilateral vocal cord paralysis $(n=2)$ and unilateral hypoglossal paralysis $(n=1)$. None of the patients had recurrence at a mean of three-year follow up.

Conclusion: Due to its complex anatomical structure and major vascular and neural contents, the surgery of PPS is still a challenge and requires the help of various equipment and technological tools. Killian's long bladed nasal speculum may aid in performing safe operations with minimal incision. Combining the technique with endoscopes or microscopes when necessary increases surgical comfort with better vision and lesser complications.
\end{abstract}

Keywords: Minimally invasive, nasal speculum, parapharyngeal space.
$\ddot{O} Z$

Amaç: $\mathrm{Bu}$ çalışmada parafarengeal bölge (PB) tümörlerinin çıkarılmasında Killian'ın nazal spekulumunun cerrahi alanın ekartasyonu ve kitlenin diseksiyonu için kullanımı konusunda klinik deneyimimiz ve cerrahi sonuçlar sunuldu.

Hastalar ve Yöntemler: Bu retrospektif çalışmaya Ocak 2014 ve Ekim 2017 tarihleri arasında PB tümörü tanısı konulan ve cerrahi olarak tedavi edilen 13 hasta (6 erkek, 7 kadın; medyan yaş 28 yıl; dağılım, 3-63 yıl) dahil edildi. Tüm hastalara nazal spekulum yardımı ile transoral veya transservikal eksizyon uyguland.

Bulgular: Parafarengeal kitleyi çıkarmak için nazal spekulum yardımı ile transoral $(n=4)$ veya transservikal $(n=9)$ eksizyon yapıldı. Dört hastada kitle malign [rabdomiyosarkom $(n=1)$, düşük evre miyofibroblastik sarkom ( $\mathrm{n}=1)$, malign schwannom $(\mathrm{n}=1)$ ve adenokarsinom $(\mathrm{n}=1)$ ] iken dokuz hastada tümör benign idi: pleomorfik adenom $(n=4)$, schwannom $(n=3)$, paraganglion $(\mathrm{n}=1)$ ve ganglionöroma $(\mathrm{n}=1)$. Ameliyat sonrası komplikasyonlar tek taraflı vokal kord paralizisi $(n=2)$ ve tek taraflı hypoglossus paralizisi $(n=1)$ idi. Ortalama üç yıllık takipte hiçbir hastada nüks görülmedi.

Sonuç: Kompleks anatomik yapısı ve majör damar ve sinir içeriği nedeniyle PB cerrahisi hala zordur ve çeşitli ekipmanlar ile teknolojik araçların yardımını gerektirir. Killian'ın uzun bıçaklı nazal spekulumu minimal insizyon ile güvenli ameliyatlar yapılmasına yardımcı olabilir. Tekniğin gerektiğinde endoskop ya da mikroskop ile birleştirilmesi daha iyi görüntü ve daha az komplikasyon ile cerrahi rahatlığı artırır.

Anahtar sözcükler: Minimal invaziv, nazal spekulum, parafarengeal bölge.

Received: March 19, 2020 Accepted: May 21, 2020 Published online: June 11, 2020

Correspondence: Emine Deniz Gözen, MD. İstanbul Üniversitesi Cerrahpaşa Tip Fakültesi, Kulak Burun Boğaz Anabilim Dalı, 34098 Fatih, İstanbul, Türkiye. e-mail: nazas39@hotmail.com 
Parapharyngeal space (PPS) tumors are rare, accounting for $0.5 \%$ of all head-and-neck masses. ${ }^{[1]}$ The PPS resembles an inverted pyramid which is divided into pre- and post-styloid compartments. The poststyloid compartment contains the internal carotid artery, internal jugular vein, sympathetic chain, and cranial nerves IX through XII. The retromandibular parotid gland and adipose tissue comprise the pre-styloid compartment. Due to its complex anatomic structure, it is challenging to remove lesions from PPS without disturbing adjacent tissues. Different surgical approaches for PPS neoplasms, including transoral/transoral robotic surgery, transcervical, parotidectomy or mandibulotomy, have been reported. When deciding for the method to be used, the surgeon should consider different keypoints including radiologic images, exposure of the surgical field, preservation of the vital structures, minimal functional and esthetic impairment, suspicion of malignancy and experience of the surgical team. The most common PPS neoplasms are salivary gland tumors, followed by neurogenic tumors. ${ }^{[2]}$ There are also reported cases of some rare entities such as lipoma. ${ }^{[3]}$ The cervical approach with or without parotidectomy is the most commonly preferred technique as it provides the best compromise between the need for radicality and low risk of damage to the neurovascular structures. By this technique, good control of the important neurovascular structures as well as good exposure of the field can be accomplished while about $6-8 \mathrm{~cm}$ of incision is needed. ${ }^{[4]}$ Some selected cases such as prestiloid tumors or tumors extending medially to the oropharynx can be resected transorally. Although transoral surgery offers quicker access to the tumor, main drawbacks are poor exposure and poor control of the vital structures. In this study, we aimed to present our clinical experience and surgical outcomes of removal of PPS tumors by the use of Killian's nasal speculum for retraction of the surgical field and dissection of the mass.

\section{PATIENTS AND METHODS}

A total of 13 patients ( 6 males, 7 females; median age 28 years; range, 3 to 63 years) diagnosed and surgically treated for PPS tumors between January 2014 and October 2017 at the Istanbul University Cerrahpaşa Faculty of Medicine were retrospectively reviewed. Patient data and images were stored in the electronic patient records. All surgeries were performed at the single institution by the senior author. The study protocol was approved by the Istanbul University Cerrahpaşa Faculty of Medicine Ethics Committee. A written informed consent was obtained from each patient or their parents. The study was conducted in accordance with the principles of the Declaration of Helsinki.
The operation was performed with the patient under general anesthesia, with nasal intubation, and in supine position. Transoral surgery was preferred in prestyloid, oropharyngeal tumors $(n=4)$, while patients with malignant tumors or patients considered to be at high risk for transoral surgery were operated with transcervical minimally invasive approach $(n=9)$.

In transcervical approach, considering the size of the tumor, $3-4 \mathrm{~cm}$ skin incision was performed $3 \mathrm{~cm}$ below the mandibular ramus. A superior subplatysmal flap was elevated to the level of the inferior border of the mandible. The posterior belly of the digastric and stylohyoid muscles was identified and divided. The internal jugular vein, common carotid artery, and its branches were identified. The hypoglossal nerve was identified and preserved. At this stage, Killian's long bladed nasal speculum was delivered through surgical incision (Figures 1, 2). Dissection was continued along the external carotid artery, and its branches were identified. The stylomandibular ligament could be divided if needed. Attention was then directed towards exposure of the tumor. The dissection was directed toward the inferolateral aspect of the tumor standing next to the mandible, up to its attachment to the lateral skull base, parotid gland, and pharynx. Extracapsular circumferential separation of the tumor from the surrounding tissues was meticulously performed, until the tumor was freed from the surrounding tissues (Figures 3, 4).

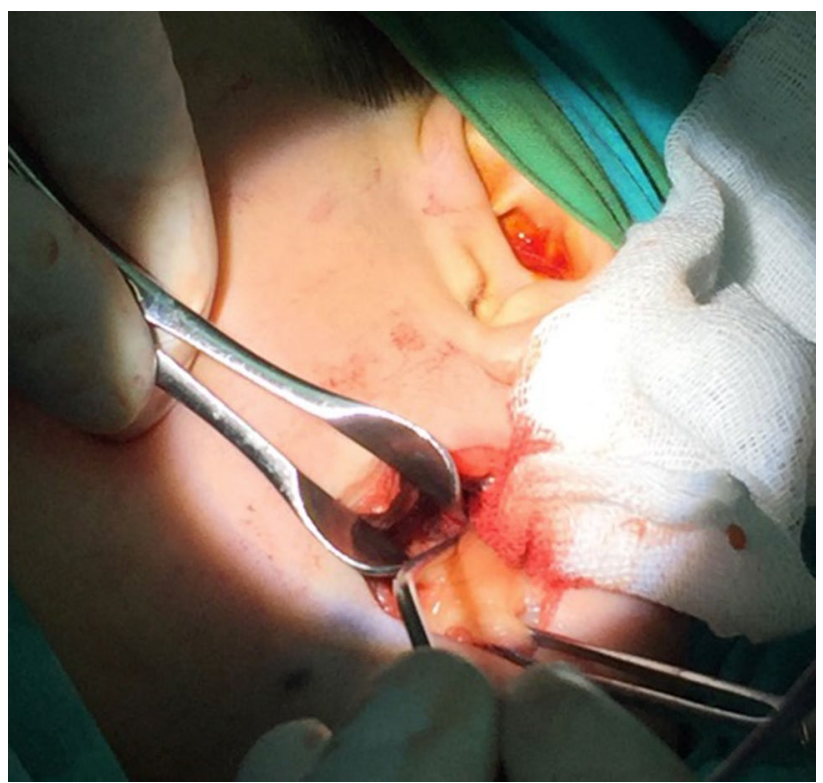

Figure 1. Killian's long bladed nasal speculum is delivered through surgical incision. 


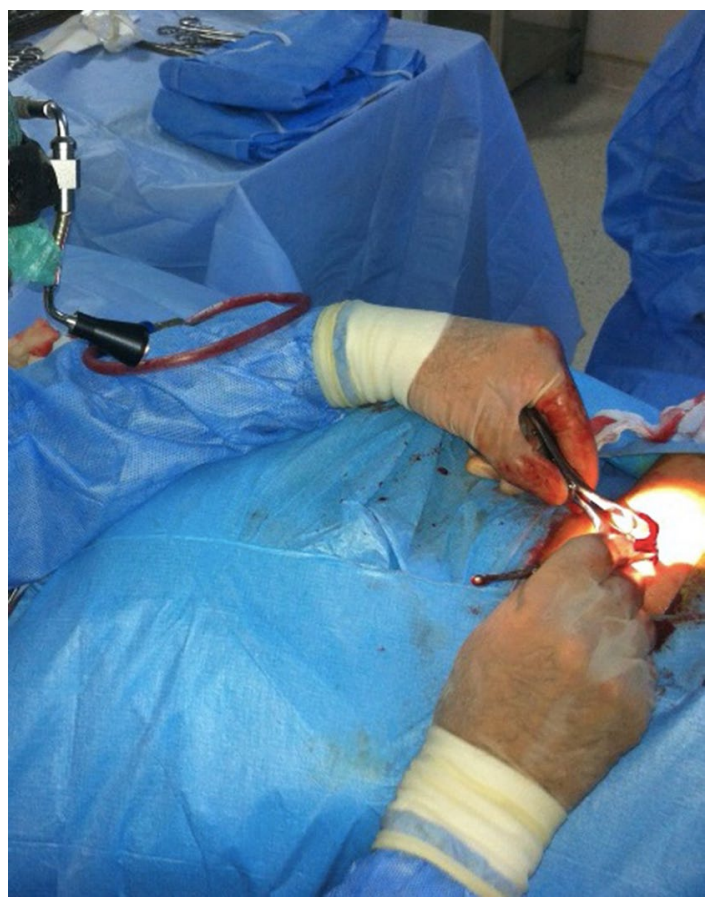

Figure 2. Surgical position.

In transoral surgery, the surgery was performed using the transoral Crockard retractor (Bahadır Tibbi Aletler AŞ., Samsun, Turkey). A lateral palatal mucosal incision was performed at the lateral aspect of the palatoglossal fold. Blunt artery forceps, a cotton ball, and a speculum were used to dissect the underlying fascia until the tumor capsule was visible. Using the Killian's long bladed nasal speculum, further separation of the tumor from surrounding tissue was performed.

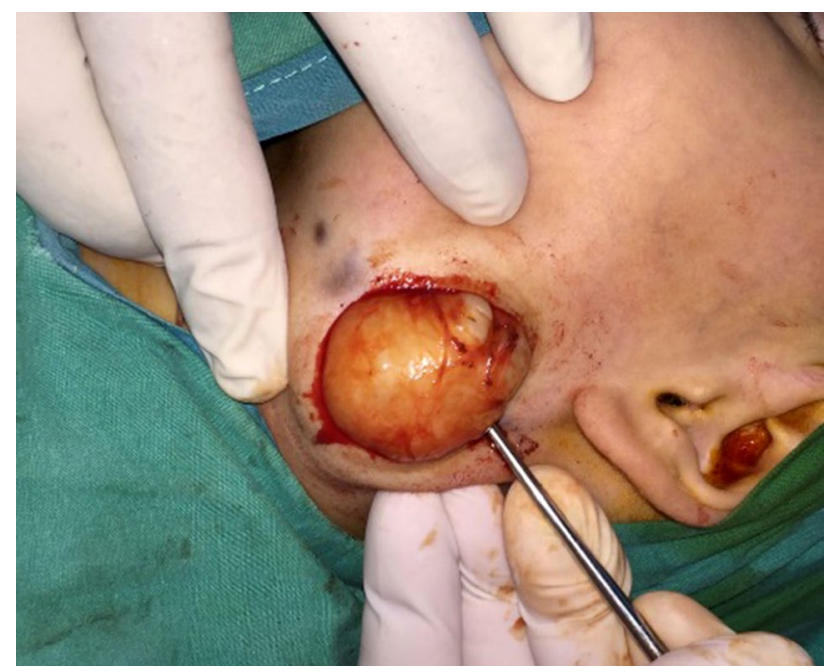

Figure 3. Removal of mass after dissection through small incision.
When necessary, exposure could be increased by combining either a microscope or an endoscope through the adequate opening provided with nasal speculum both in transcervical and transoral approaches.

\section{Statistical analysis}

Descriptive analysis (age, gender, surgical approach and pathology) were performed with Microsoft (Las Vegas, NV, USA) Excel Programme.

\section{RESULTS}

We successfully performed nasal speculum-assisted transoral $(n=4)$ or transcervical $(n=9)$ excision of PPS tumors in 13 patients. General characteristics and pathologies of the patients were presented in Table 1. The median follow-up duration was 26 months (range, 2 to 46 months). The pathologic reports revealed four patients of malignancy (30.7\%) [rhabdomyosarcoma $(n=1)$, low grade myofibroblastic sarcoma $(n=1)$, malignant schwannoma $(n=1)$ and adenocarcinoma $(n=1)]$. The benign tumors $(69.2 \%)$ were pleomorphic adenoma $(n=4)$, schwannoma $(n=3)$, paraganglioma $(n=1)$ and ganglioneuroma $(n=1)$. Two of the patients with malignancy had permanent unilateral vocal cord paralysis and one $(7.6 \%)$ of these patients had unilateral hypoglossal paralysis due to sacrifice of hypoglossal nerve for tumor invasion (malignant schwannoma). Most patients only had mild tenderness on the operation area. There was no additional morbidity such as bleeding, facial palsy, hoarseness or Horner's syndrome during the postoperative period. After a short hospitalization period of about three days, patients were discharged. Regular outpatient follow-up magnetic resonance imaging and physical

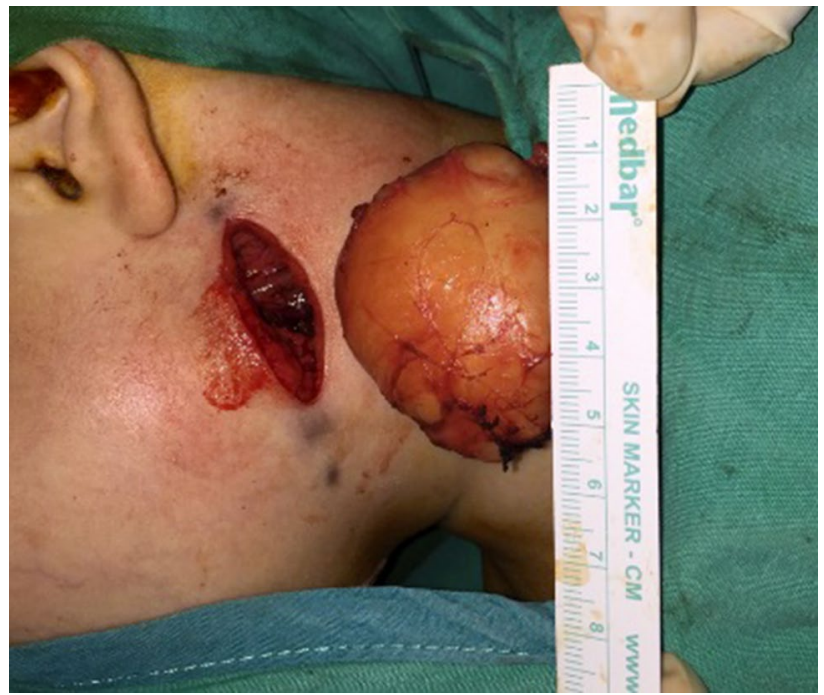

Figure 4. Totally excised mass. 


\begin{tabular}{|lccc|}
\hline \multicolumn{4}{c|}{ Table 1 } \\
& General characteristics and pathologies of patients & Complication \\
Pathology & Age/Gender & Surgical approach & \\
Benign (69.2\%) & & Transoral & \\
Pleomorfic adenoma & $28 / \mathrm{F}$ & Transoral & \\
Pleomorfic adenoma & $32 / \mathrm{M}$ & Transcervical & \\
Pleomorfic adenoma & $63 / \mathrm{F}$ & Transcervical & \\
Pleomorfic adenoma & $44 / \mathrm{F}$ & Transoral & \\
Schwannoma & $37 / \mathrm{F}$ & Transcervical & \\
Schwannoma & $30 / \mathrm{F}$ & Transcervical & \\
Schwannoma & $45 / \mathrm{M}$ & Transcervical & \\
Paraganglioma & $36 / \mathrm{F}$ & Transcervical & \\
Ganglioneuroma & $5 / \mathrm{M}$ & & \\
Malignant (30.7\%) & & Permanent CN10 paralysis \\
Rhabdomyosarcoma & $3 / \mathrm{M}$ & Transcervical & \\
Myofibroblastic sarcoma & $8 / \mathrm{M}$ & Transoral & \\
Malignant schwannoma & $42 / \mathrm{F}$ & Transcervical & CN12 paralysis-permanent \\
Adenocarcinoma & $46 / \mathrm{M}$ & Transcervical & CN10 paralysis \\
\hline
\end{tabular}

examinations revealed no recurrent lesions in any of the patients.

\section{DISCUSSION}

The PPS tumors account for $0.5 \%$ of head and neck tumors and management of these tumors can be challenging due to the anatomical complexity of this area and adjacent critical neurovascular structures. ${ }^{[1]}$ When determining the best way to approach PPS tumors, the size and pathology of the tumor must be considered. However, surgeon preference and experience of the surgical team also influence the decision. The surgical approaches to be considered include, but are not limited to, the transoral approach, the transcervical approach, the transoral and transcervical combination approach, the transcervical approach with mandibulotomy, the transfacial approach, the transparotid approach, and the lateral skull base. ${ }^{[2-6]}$

The conventional transcervical approach for PPS tumors offers better surgical exposure and better identification of the vital structures with minimal complication rates while the main disadvantage is large skin incision. The transoral approach for PPS tumors was first described by Goodwin and Chandler ${ }^{[7]}$ in 1988. The technique was preferred to be used for small, benign and medial PPS tumors with no involvement of the styloid process. The key advantage of this approach is the absence of external facial scar formation. Yet, the disadvantages may outweigh this aesthetic advantage. The transoral approach brings along higher rates of uncontrollable bleeding, nerve injury and unsatisfactory surgical margins, which increased the recurrence rate up to $25 \%$ in their patients.

The recent advances in modern surgery by use of endoscopes and robotic surgery have widened the options for PPS tumor operations. ${ }^{[8]}$ Wang et al. ${ }^{[9]}$ utilized endoscope-assisted transoral surgery in 20 patients and found that the technique resulted in decreased blood loss, shorter hospitalization period, less postoperative pain and no neck scar. Beswick et al. $^{[10]}$ preferred an endoscope-assisted minimally invasive transcervical approach for pre-styloid PPS tumors and managed to preserve the auricular nerve. Although preliminary results of transoral robotic surgeries for selected oropharyngeal lesions have been reported to be promising, robotic surgery requires more strict patient selection, is more time-consuming and has higher medical costs. All these limitations have made robotic surgeries unviable for the general population. ${ }^{[11]}$

Here, we suggest that Killian's long bladed nasal speculum may help improve exposure through a small incision and instantly manage the important structures safely. Leakage-type bleeding from surrounding tissues is decreased with its pressure effect and it can be combined with a microscope or an endoscope. While the use of Killian's long bladed nasal increases the surgeon's comfort, even in selected cased that require mandibulotomy, it can maintain adequate exposure and assure safe surgery without mandibulotomy. 
The complications of PPS tumor surgeries are bleeding, cranial nerve paralysis, Horner's syndrome, first bite syndrome, lockjaw, hematoma and Frey syndrome. The overall most common complication is cranial nerve injury. In their systematic literature review of 1,143 cases, Riffat et al. ${ }^{[12]}$ found that $14 \%$ of the patients experienced vagus nerve paralysis, which was the most common, followed by facial nerve injury (12\%) and hyposlossus paralysis (6\%). Even though the number of cases in our study is limited, two of the patients had permanent vocal cord paralysis and one of these patients had unilateral hypoglossal paralysis due to the scarification of the hypoglossal nerve. In our modification, as blind dissection was avoided by increasing the exposure with the help of nasal speculum, the complication rate of our series is low. Also, surgical bleeding was decreased with the pressure effect of nasal speculum to surrounding tissues which improves visualization. Although retraction and exposure of this region are challenging, the patients in our series were operated in a more controlled fashion with minimal complication rates.

The number of the patients is limited and follow-up period of the patient is not long enough.

In conclusion, due to its complex anatomical structure and major vascular and neural contents, the surgery of PPS is still a challenge and requires the help of various equipment and technological tools. Killian's long bladed nasal speculum may aid in performing safe operations with minimal incision. Combining the technique with endoscopes or microscopes when necessary increases surgical comfort with better vision and lesser complications.

\section{Declaration of conflicting interests}

The authors declared no conflicts of interest with respect to the authorship and/or publication of this article.

\section{Funding}

The authors received no financial support for the research and/or authorship of this article.

\section{REFERENCES}

1. Olsen KD. Tumors and surgery of the parapharyngeal space. Laryngoscope 1994;104:1-28.

2. Paderno A, Piazza C, Nicolai P. Recent advances in surgical management of parapharyngeal space tumors. Curr Opin Otolaryngol Head Neck Surg 2015;23:83-90.

3. Korkmaz MO, Cesur S, Asil K, Guven M. Lipoma in the deep lobe of parotid gland extending to parapharyngeal space: Case report. KBB Uygulamalar1 2017;5:116-9.

4. Özcan M, Tuncel Ü, Ünal A, Arda N, Yalçın F. Parafaringeal kitlelere transservikal- transmandibuler yaklaşım: Dört olgunun sunumu. KBB-Forum 2002;1:48-53.

5. Chang SS, Goldenberg D, Koch WM. Transcervical approach to benign parapharyngeal space tumors. Ann Otol Rhinol Laryngol 2012;121:620-4.

6. Dimitrijević MV, Jesić SD, Krstić AM, Bjelogrlić GM, Stojković GM. [Surgical approach to parapharyngeal space tumors]. Acta Chir Iugosl 2011;58:61-6.

7. Goodwin WJ Jr, Chandler JR. Transoral excision of lateral parapharyngeal space tumors presenting intraorally. Laryngoscope 1988;98:266-9.

8. Lee HS, Kim J, Lee HJ, Koh YW, Choi EC. Transoral robotic surgery for neurogenic tumors of the prestyloid parapharyngeal space. Auris Nasus Larynx 2012;39:434-7.

9. Wang X, Gong S, Lu Y, Pan X, Luo X, Sun H. Endoscopyassisted transoral resection of parapharyngeal space tumors: a retrospective analysis. Cell Biochem Biophys 2015;71:1157-63.

10. Beswick DM, Vaezi A, Caicedo-Granados E, Duvvuri U. Minimally invasive surgery for parapharyngeal space tumors. Laryngoscope 2012;122:1072-8.

11. Boyce BJ, Curry JM, Luginbuhl A, Cognetti DM. Transoral robotic approach to parapharyngeal space tumors: Case series and technical limitations. Laryngoscope 2016;126:1776-82.

12. Riffat F, Dwivedi RC, Palme C, Fish B, Jani P. A systematic review of 1143 parapharyngeal space tumors reported over 20 years. Oral Oncol 2014;50:421-30. 